\title{
Genome Sequence of Brevundimonas sp., an Arsenic Resistant Soil Bacterium
}

\author{
Javiera Soto ${ }^{1,2}$, Trevor C. Charles ${ }^{3,4}$, Michael D. J. Lynch ${ }^{3,4}{ }^{\oplus}$, Giovanni Larama ${ }^{5}{ }^{\oplus}$, Hector Herrera ${ }^{1} \mathbb{C}$ \\ and César Arriagada $1, * \mathbb{B}$
}

1 Laboratorio de Biorremediación, Facultad de Ciencias Agropecuarias y Forestales, Universidad de La Frontera, Francisco Salazar, Temuco 01145, Chile; javiera.soto@ufrontera.cl (J.S.); hector.herrera@ufrontera.cl (H.H.)

2 Scientific and Technological Bioresource Nucleus, Universidad de La Frontera, Francisco Salazar, Temuco 01145, Chile

3 Department of Biology, University of Waterloo, 200 University Avenue West, Waterloo, ON N2L 3G1, Canada; trevor.charles@waterloo.ca (T.C.C.); mdjlynch@gmail.com (M.D.J.L.)

4 Metagenom Bio, A9-550 Parkside Drive, Waterloo, ON N2L 5V4, Canada

5 Centro de Excelencia de Modelación y Computación Científica, Universidad de La Frontera, Francisco Salazar, Temuco 01145, Chile; giovanni.larama@ufrontera.cl

* Correspondence: cesar.arriagada@ufrontera.cl; Tel.: +56-45-232-5662

Citation: Soto, J.; Charles, T.C.; Lynch, M.D.J.; Larama, G.; Herrera, H.; Arriagada, C. Genome Sequence of Brevundimonas sp., an Arsenic Resistant Soil Bacterium. Diversity 2021, 13, 344. https://doi.org/ $10.3390 / \mathrm{d} 13080344$

Academic Editors: Michael Wink and Maria Teresa Ceccherini Guicciardini

Received: 9 June 2021

Accepted: 14 July 2021

Published: 27 July 2021

Publisher's Note: MDPI stays neutral with regard to jurisdictional claims in published maps and institutional affiliations.

Copyright: (c) 2021 by the authors. Licensee MDPI, Basel, Switzerland. This article is an open access article distributed under the terms and conditions of the Creative Commons Attribution (CC BY) license (https:// creativecommons.org/licenses/by/ $4.0 /)$.
Abstract: Brevundimonas sp. is a bacteria able to grow in metal(loid) contaminated soil from Puchuncaví Valley, central Chile. This study has isolated a bacterial strain capable of growth under high doses of arsenic (As) (6000 $\left.\mathrm{mg} \mathrm{L}^{-1}\right)$, and a draft genome sequence was generated. Additionally, real-time PCR was performed to examine the effect of As on some genes related to As resistance. Results demonstrated a total of 3275 predicted annotated genes with several genes related to the ars operon, metal(loid) resistance-related genes, metal efflux pumps, and detoxifying enzymes. Real-time PCR showed that the arsB involved in the efflux of As was down-regulated, whereas ars $\mathrm{R}, \operatorname{arsH}$, and $A C R 3$ did not show differences with the addition of As. Our study provides novel evidence of diverse As regulating systems in tolerant bacteria that will lead to a better understanding of how microorganisms overcome toxic elements and colonize As contaminated soils and to the possible use of their specific properties in bioremediation.

Keywords: Brevundimonas sp.; arsenic; draft genome; metal(oid)s tolerance

\section{Introduction}

Arsenic (As) is a metalloid ubiquitous in the environment with origins from natural sources and anthropogenic activities [1]. These activities include the burning of fossil fuels and the use of agricultural pesticides and fertilizers, which contribute to the abundance of As in the environment [2]. The As metalloid is potentially harmful to human health in cases of direct contact and bioaccumulation, causing several diseases and different pathologies ranging from neurological disorders to the development of cancer [3-5]. In ecosystems, As can affect plant development, growth, and productivity due to an abundance of morphological, physiological, biochemical, and molecular alternations [6], such as reduced root elongation, suppression in the number of leaves and leaf area, thereby reducing photosynthesis and biomass accumulation [7], in addition, reduces the rate of photosynthesis and interferes with the synthesis of chlorophyll [8]. Also, inactivate key enzymes through interaction with sulfhydryl groups (-SH) or by replacement of ions from their active sites [9]. Furthermore, it has deleterious effects on carbohydrate and lipid metabolism, among others [6].

The toxicity of As to plants depend on the speciation of the metalloid in the environment. Such toxicity will depend on factors such as redox potential, $\mathrm{pH}$, organic matter, and moisture content, all of this determining its mobility in the soil [10]. As can exist in 
both organic and inorganic forms. The inorganic forms arsenate $\left(\mathrm{AsV} ; \mathrm{AsO}_{4}{ }^{3-} / \mathrm{H}_{3} \mathrm{AsO}_{4}\right)$ and arsenite (AsIII; $\mathrm{AsO}_{3}{ }^{3-} / \mathrm{H}_{3} \mathrm{AsO}_{3}$ ) are more toxic than organic forms like arsenobetaine or arsenosugars that are recognized as non-toxic [11,12]. The most dangerous biochemical effect of As at the subcellular level is the production of the reactive oxygen species (ROS) such as superoxide radical $\left(\mathrm{O}_{2}{ }^{-}\right)$, hydroxyl radical $(\mathrm{OH})$, and hydrogen peroxide $\left(\mathrm{H}_{2} \mathrm{O}_{2}\right)[13,14]$, and can cause unrepairable damage to important macromolecules, including lipids, proteins, carbohydrate, and DNA $[15,16]$.

Microorganisms have developed different mechanisms such as methylation, reduction, and oxidation to transform AsIII to the less toxic form AsV [17]. Microbial-mediated processes involved in the reduction or oxidation of As are environmentally important since they can produce a change in the oxidation state, thereby changing the bioavailability and toxicity $[18,19]$. Several authors [20-22] reported that microbes that can withstand a high concentration of As could be potentially used for the bioremediation of As.

For As-resistant bacteria, the As detoxification processes mainly depend on their ars operons [23]. Resistance mechanisms to As involve an influx/efflux system that is encoded by the ars operon. The two most common types of these operons contain either five (arsRDABC) or three (arsRBC) genes [24]. ArsC encodes an AsV reductase enzyme that reduces AsV to AsIII prior to efflux. The AsIII produced is exported out of the cell by an AsIII efflux pump encoded by arsB, often associated with an ATPase subunit, ars $A$ [25]. $A r s R$ and $\operatorname{ars} D$ have a regulatory role, with ars $R$ encoding a repressor involved in the basal regulation of the ars operon, while ars $D$ is a second repressor controlling the upper levels of ars genes expression [26].

Bacteria of the genus Brevundimonas have been isolated from a wide variety of environments and often exhibit the ability to promote plant growth [27]. Additionally, they may protect plants from heavy metals toxicity and other environmental stresses [28,29]. This study evaluated AsV resistance in a newly isolated Brevundimonas strain and identified the As and heavy metal-resistance genes based on draft genome sequencing and gene annotations.

The objective of this study was (i) to understand Brevundimonas As-resistant mechanisms and (ii) to explore its potential roles in As transformation in the environment.

\section{Materials and Methods}

\subsection{Soil Sampling and Bacteria Isolation}

The soil used for bacterial isolation was collected from the rhizosphere of three Oenothera picensis plants, located in the Puchuncaví Valley in the coastal area of central Chile (Valparaiso Region), $1.5 \mathrm{~km}$ southeast of the Ventanas copper smelter $\left(32^{\circ} 46^{\prime} 30^{\prime \prime} \mathrm{S}\right.$; $71^{\circ} 28^{\prime} 17^{\prime \prime} \mathrm{W}$ ). This plant was selected for being one of the few that grow in this place. This ecosystem has been subjected to large quantities of gaseous and metal-rich particulate pollution from the copper smelter since 1964 [30]. Among the metal(loid)s found in the soil are copper $(\mathrm{Cu})$, zinc $(\mathrm{Zn})$, lead $(\mathrm{Pb})$ and $\mathrm{As}\left(385,183,135\right.$, and $52 \mathrm{mg} \mathrm{kg}^{-1}$, respectively) [31].

To isolate the bacteria, $1 \mathrm{~g}$ of rhizospheric soil was agitated in sterile distilled water and shaken for $30 \mathrm{~s}$; then serial dilution method was performed on Luria-Bertani (LB) agar plates (10 g tryptone, $10 \mathrm{~g} \mathrm{NaCl}, 5 \mathrm{~g}$ yeast extract, $12 \mathrm{~g}$ agar per liter) supplemented with $50 \mathrm{mg} \mathrm{L}^{-1}$ of AsV $\left(\mathrm{Na}_{2} \mathrm{AsO}_{4} \cdot 7 \mathrm{H}_{2} \mathrm{O}\right.$, Sigma-Aldrich, St. Luis, MO, USA). After 3-4 days of incubation, distinct morphotypes of bacteria were screened based on colony color, shape, and size. Each morphotype was purified by re-streaking on a fresh LB agar plate and the purified isolates were maintained at $4{ }^{\circ} \mathrm{C}$.

\subsection{Arsenic Resistance}

To test As resistance, the strains were incubated in LB medium plus $\mathrm{As}(\mathrm{V})$, the concentrations used ranged from 500 to $8000 \mathrm{mg} \mathrm{L}^{-1}$, in $500 \mathrm{mg} \mathrm{L}^{-1}$ increments, at $28^{\circ} \mathrm{C}, 200 \mathrm{rpm}$. After $48 \mathrm{~h}$ of incubation, the OD600 was recorded. Brevundimonas sp. B10 was selected, subsequently identified, and used for the following assays. 


\subsection{Molecular Identification of Bacteria}

The DNA extraction was performed by selecting the strain and incubating it in LB broth medium at $28{ }^{\circ} \mathrm{C}, 200 \mathrm{rpm}$ for $48 \mathrm{~h}$, and centrifuged at $8000 \times \mathrm{g}$ for $7 \mathrm{~min}$. The pellet was used for DNA extraction using the UltraClean ${ }^{\circledR}$ Microbial DNA Isolation Kit (MO-BIO Laboratories, Carlsbad, CA, USA) according to the manufacturer's instructions. The $16 \mathrm{~S}$ rRNA gene was amplified using PCR with universal primers 27F (5'-AGAGTTTGATCCTGGCTCAG-3') and 1492R (5'-TACGGTTACCTTGTTACGACTT$\left.3^{\prime}\right)$ according to Banerjee, et al. [32] and sequenced in Macrogen (Seoul, South Korea). The resulting sequences were queried against the GenBank 16 rRNA database (http: //www.ncbi.nlm.nih.gov/, accessed on 18 January 2018) using MOLE-BLAST to find the closest known sequences. The genome was also queried in automated multilocus species tree (autoMLST) [33] server to identify close genomes from NCBI database. The phylogenetic analyses of the $\operatorname{ars} R, \operatorname{ars} B$, and $\operatorname{ars} C$ genes of Brevundimonas sp. B10 and other bacteria containing the ars operon were performed by aligning the concatenated protein sequences of $\operatorname{ars} R, \operatorname{ars} B$, and $\operatorname{ars} C$ genes with the MUSCLE algorithm. The resulting alignment was used to find the best-fit substitution model by Maximum Likelihood, and gaps/missing data were treated with partial deletion with site coverage cut-off of $95 \%$. The final tree was constructed with WAG + G model by Maximum Likelihood over 526 informative positions. The stability of the tree was evaluated by the bootstrap method with 1000 replications. All these analyses were performed in the Molecular Evolutionary Genetics Analysis software [34].

\subsection{Growth Conditions and Genomic DNA Preparation for Sequencing}

Brevundimonas sp. B10 was cultured in $10 \mathrm{~mL}$ of liquid LB medium at $28^{\circ} \mathrm{C}$ for $48 \mathrm{~h}$ with $200 \mathrm{rpm}$ shaking. For genomic DNA isolation, bacterial cells of $0.5 \mathrm{~mL}$ were collected by centrifugation at $20,000 \times g$ for $3 \mathrm{~min}$. After removing the supernatant, the cell pellet was resuspended in $0.75 \mathrm{~mL}$ Sox1 solution and then transferred into a bead tube of Sox DNA Isolation Kit (Metagenom Bio, Waterloo, ON, Canada). Cell lysis was performed at $4 \mathrm{M} / \mathrm{s}$ for $40 \mathrm{~s}$ using the FastPrep-24 Instrument (MP Biochemicals, Santa Ana, CA, USA). Lysate was recovered by centrifuging at $20,000 \times g$ for $5 \mathrm{~min}$ and transferred into a $1.5 \mathrm{~mL}$ tube containing $5 \mu \mathrm{L}$ of RNase A solution $(10 \mathrm{mg} / \mathrm{mL})$. Following incubation for $10 \mathrm{~min}$, $1.5 \mathrm{~mL}$ of Sox solution 3 was added and mixed. Purification of genomic DNA using a spin column was carried out according to the supplier's instructions.

Genomic DNA concentration was quantified using a NanoDrop 2000 spectrophotometer (ThermoFisher). The quality of DNA prep was also checked with $0.8 \%$ TAE agarose gel.

\subsection{Genome Sequencing and Assembly}

The genome of Brevundimonas sp. isolate B10 was sequenced with the MiSeq platform (Metagenom Bio Inc., Waterloo, ON, Canada) using the Nextera DNA Flex Library Preparation Kit and the MiSeq Reagent Kit v2 in the paired-end mode for 251 cycles. Sequencing and quality control resulted in 942,471 high-quality reads used to create a de novo assembly of Brevundimonas sp. B10 strain using SPAdes v3.11 [35]. This assembly was used as the primary input to GFinisher [36] along with alternate de novo assemblies from MEGAHIT v1.1.2 [37] and ABySS v2.0.2 [38]. The resulting scaffolds were submitted to Rapid Annotations using Subsystems Technology (RAST) server (http:/ / rast.nmpdr.org, accessed on 18 January 2018) [39] for their annotation where Prodigal [40] is used for gene calling. The completeness of the genome was assessed using BUSCO [41], with alphaproteobacteria_odb10 database as a query.

\subsection{As-Resistance Related Genes Expression Assay}

Brevundimonas sp. B10 was grown in LB broth amended with 0, 500, and $1000 \mathrm{mg} \mathrm{L}^{-1} \mathrm{AsV}$, and incubated at $28^{\circ} \mathrm{C}$ under shaking conditions $(200 \mathrm{rpm})$ for $48 \mathrm{~h}$. Culture without the addition of metalloid served as control. Experiments were conducted in triplicate with 2 technical replicates each. Total RNA was isolated using SV Total RNA Isolation System (Promega, 
WI, USA) following the manufacturer's instructions. Final elution was made with $50 \mu \mathrm{L}$ of DNase-free water (DEPC), and concentration for each sample was quantified in MaestroNano ${ }^{\circledR}$ spectrophotometer (MaestroGen, Hsinchu City, Taiwan). To avoid sample contamination with genomic DNA and false positives in the RT-qPCR, RNA samples (10 mg) were treated with an RNase-free DNase I Set (E.Z.N.A, Omega Bio-Tek, Norcross, GA, USA). The integrity and quality were verified by denaturing gel electrophoresis. RNA was stored at $-80{ }^{\circ} \mathrm{C}$ until its use.

Reverse transcription was performed with $1 \mu \mathrm{g}$ RNA using AffinityScript QPCR cDNA Synthesis Kit (Agilent Technologies, Santa Clara, CA, USA). Primers for real-time PCR, listed in Table 1, were designed using AmplifX 1.7.0 [42] based on the draft genome sequence determined in this study. The rpoB, gap, and rho genes were chosen as candidates for reference genes. Real-time PCR reaction mixtures contained $10 \mu \mathrm{L}$ PowerUp ${ }^{\mathrm{TM}} \mathrm{SYBR}^{\mathrm{TM}}$ Green Master Mix (Applied Biosystems, Foster City, CA, USA), 10 mmoles of each primer, $2 \mu \mathrm{L}$ template $(10 \times$ diluted cDNA from cultures), and nuclease-free sterile distilled water to a total volume of $20 \mu \mathrm{L}$. The relative expression quantification was carried out in a StepOnePlus Thermocycler (Applied Biosystems). Thermal conditions were $95{ }^{\circ} \mathrm{C}$ for $10 \mathrm{~min}$ followed by 40 cycles of $95^{\circ} \mathrm{C}$ for $15 \mathrm{~s}, 60^{\circ} \mathrm{C}$ for $15 \mathrm{~s}$ and $72{ }^{\circ} \mathrm{C}$ for $15 \mathrm{~s}$. All reactions were performed in triplicate. Primers for real-time PCR analyses were designed from the sequences of Brevundimonas sp. B10 genome. Each primer was tested in silico in an attempt to avoid discard dimer formation. Target genes ( $\operatorname{ars} B, \operatorname{ars} R, A C R 3$, and $\operatorname{arsH})$ are related to As-resistance.

Table 1. Set of primers used in this study for the relative expression assay of genes involved in arsenic resistance in Brevundimonas sp. B10. * Housekeeping genes.

\begin{tabular}{|c|c|c|}
\hline Gene & Sequence $5^{\prime}-3^{\prime}$ & Length (pb) \\
\hline \multirow[t]{2}{*}{$\operatorname{ars} B$} & GGGCATGTATCTGGTGGTCT & 165 \\
\hline & AGGACAGTCGGCATGTTGTT & \\
\hline \multirow[t]{2}{*}{$\operatorname{ars} R$} & CGGTGACATCTCCAACCATC & 165 \\
\hline & TCCTTGAGCAGGAAGAGGAC & \\
\hline \multirow[t]{2}{*}{ ACR3 } & ATCAGCCGGAATACATGACC & 164 \\
\hline & CCAGGCATAAAGGCTGAAGA & \\
\hline \multirow[t]{2}{*}{$\operatorname{arsH} 2$} & CTTCCAGGAGTTCGACGG & 165 \\
\hline & CGGACCAGAATGGTGAAG & \\
\hline \multirow[t]{2}{*}{${ }^{*} r p o B$} & CATCTATCGCCTGTCGAAGTTCCA & 196 \\
\hline & GTCTTCGAAGTTGTAGCCGTTCCA & \\
\hline \multirow{2}{*}{ *gap } & GACCATCGTCTACAAGGTCAACCA & 196 \\
\hline & GATCCTTGTGCATCGTATCCAG & \\
\hline \multirow[t]{2}{*}{ * rho } & AACATCGCCAAGTCGATCGAGA & 187 \\
\hline & GCTTGGCCTTTTCGATCACCAT & \\
\hline
\end{tabular}

\subsection{Data Analyses}

geNorm $^{\mathrm{TM}}$ [43] and NormFinder [44] algorithms were used to evaluate the stability of candidate reference gene expression using the $\mathrm{Ct}$ values transformed to relative quantities as input. Gene expression data were compared by analysis of variance followed by Tukey's multiple range test. Statistical analyses were conducted using StatSoft Inc. (2004) STATISTICA (Data Analysis Software System), Version 7.

\section{Results}

\subsection{Bacteria Identification and As-Resistance}

We selected the strain Brevundimonas sp. B10 for the following experiments due to the high As-resistance and the demonstration in previous assays that it can increase tolerance to heavy metals in wheat plants [31]. The selected bacteria showed $100 \%$ identity with Brevundimonas intermedia (Accession number KR811205.1), meanwhile, the genome evaluated in autoMLST showed that the closest genomes in the NCBI database measured as Average Nucleotide Index (ANI) are from Brevundimonas genus, having Brevundimonas 
sp. assembly code GCF_001422455 the highest ANI of 90.5\%. The minimum inhibitory concentrations (MIC) of the strain was $6000 \mathrm{mg} \mathrm{L}^{-1}$ of AsV.

The phylogenetic tree (Figure 1) of ars genes of Breoundimonas sp. B10 showed greater closeness to Corybacterium efficiens and Acidithiobacillus ferridurans.

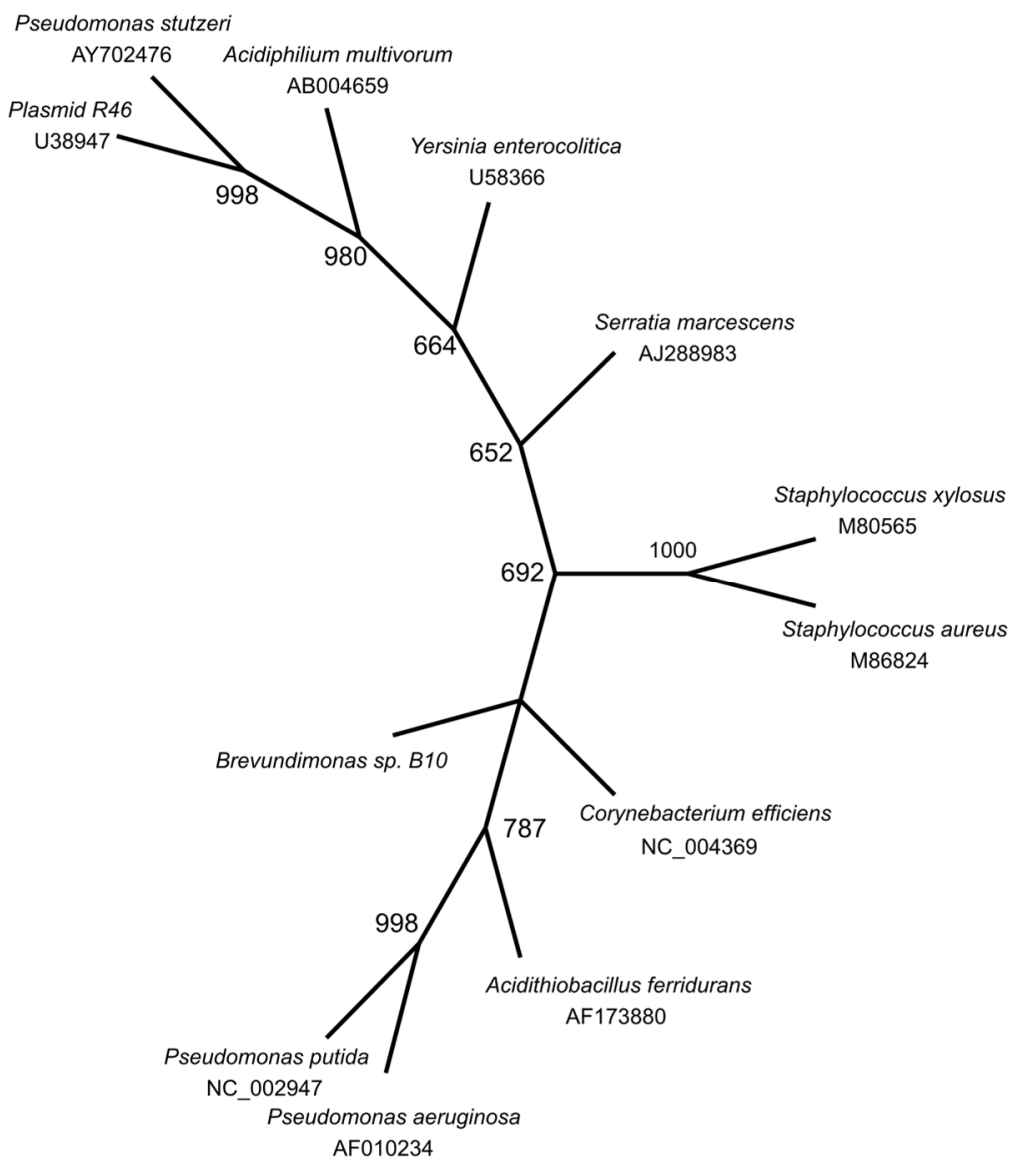

Figure 1. Phylogenetic tree of the $\operatorname{ars} R$, $\operatorname{ars} B$, and $\operatorname{ars} C$ genes of Brevundimonas sp. B10 and other bacterias containing the ars operon using WAG + G model by Maximum Likelihood over 526 informative positions. The stability of the tree was evaluated by the bootstrap method with 1000 replications.

\subsection{Genome Properties}

The draft genome sequence of Brevundimonas sp. B10 strain is 3,343,585 bp long contained in 7 scaffolds with a G $+C$ content of $66.5 \%$ and an N50 value of $1,543,057 \mathrm{bp}$. The search for conserved orthologs genes (BUSCO) showed no missing BUSCO genes, and 99.5\% completed BUSCO genes, indicating a high degree of completeness (Table S3). It has 3275 predicted genes including $3185(97.25 \%)$ protein-coding genes, $58(1.78 \%)$ RNA genes, and $32(0.97 \%)$ pseudogenes. A total of $1391(42.47 \%)$ genes were classified inside a SEED subsystem (Figure 2). More detailed information on the genome statistics is shown in Table S1. The genome sequencing project information is summarized in Table S2 and the sequences were deposited in the BioProject PRJNA505530 and the Genbank ID accession number is SPVH00000000.1. 


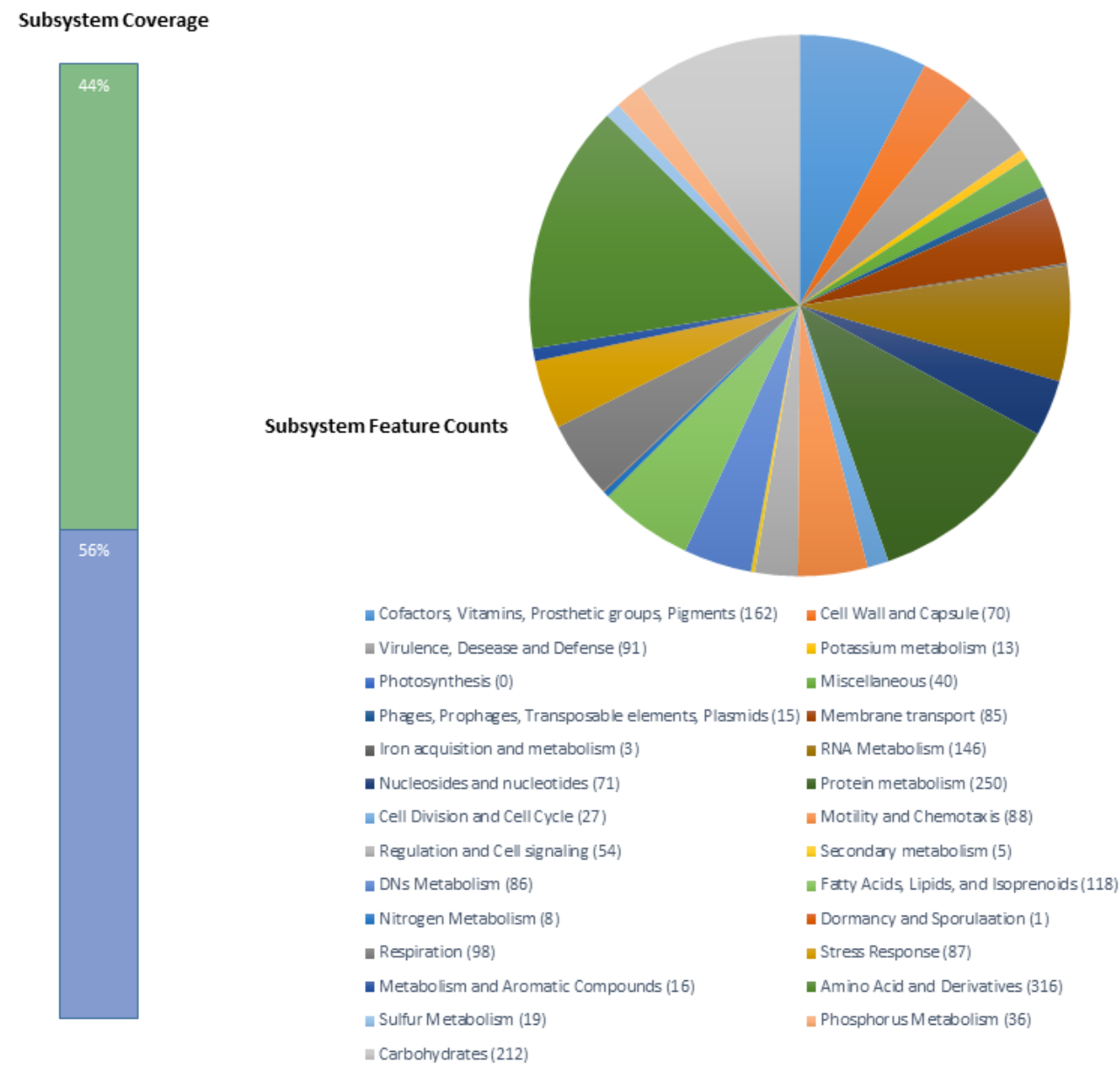

Figure 2. Subsystems distribution statistic of Brevundimonas sp. B10, based on RAST annotation server.

\subsection{Insights from the Genome Sequence}

Genome analysis showed 82 protein-coding genes associated with virulence, disease, and defense systems, among which, 62 belong to the defense subsystem and highlight those of resistance to metals that include $\mathrm{Cu}-\mathrm{Zn}-\mathrm{Cd}$ resistance, As resistance, $\mathrm{Cu}$ tolerance, resistance to chromium compounds, and multidrug resistance efflux pump (Table 2).

Table 2. Protein coding genes associated with the defense subsystem of Brevundimonas sp. B10.

\begin{tabular}{cc}
\hline Value & Defense Subsystems \\
\hline 7 & Colicin V and Bacteriocin Production Cluster \\
21 & Copper homeostasis \\
24 & Copper-zinc-cadmium resistance \\
8 & Arsenic resistance \\
2 & Coper homeostasis: copper tolerance \\
4 & Resistance to fluoroquinolones \\
5 & Beta-lactamase \\
6 & Multidrug-resistance Efflux pump \\
1 & Resistance to chromium compounds \\
\hline
\end{tabular}

Among As-resistance genes (Table 3), we found two ars operons. One of the operons (arsRBCH type) is constituted by an arsenite-responsive transcriptional regulator gene $(\operatorname{ars} R)$, arsenite efflux pump gene $(\operatorname{ars} B)$, arsenate reductase gene $(\operatorname{ars} C)$, and NADPHdependent flavin mononucleotide reductase gene $(\operatorname{arsH})$ gene. The second operon (arsRCH ( $A C R 3)$ type) contains an arsenite-responsive transcriptional regulator gene (arsR), an arsenate reductase gene $(\operatorname{ars} C)$, an NADPH-dependent flavin mononucleotide reductase 
gene $(\operatorname{ars} H)$ gene, and one arsenite permease gene (ACR3). The genetic organization of the two arsenic-resistance operons is shown in Figure 3.

Table 3. List of arsenic resistance-related genes found in Brevundimonas sp. B10.

\begin{tabular}{cccc}
\hline Putative Gene & Annotation & Size (aa) & Accession Number \\
\hline arsH & Arsenic resistance protein & 247 & TFW12232.1 \\
ars $C$ & Arsenate reductase & 142 & TFW12233.1 \\
arsR & Transcriptional regulator & 112 & TFW12234.1 \\
arsB & Arsenic efflux pump protein & 427 & TFW12235.1 \\
ars 2 & Transcriptional regulator 2 & 111 & TFW11216.1 \\
ars 2 & Arsenate reductase 2 & 141 & TFW11215.1 \\
ACR3 & Arsenical resistance protein & 361 & TFW11214.1 \\
arsH2 & Arsenic resistance protein 2 & 250 & TFW11212.1 \\
ars $\mathrm{C} 3$ & Arsenate reductase 3 & 88 & TFW15101.1 \\
$\operatorname{arsH3}$ & Arsenic resistance protein 3 & 252 & TFW13512.1 \\
\hline
\end{tabular}

\section{Contig 8}

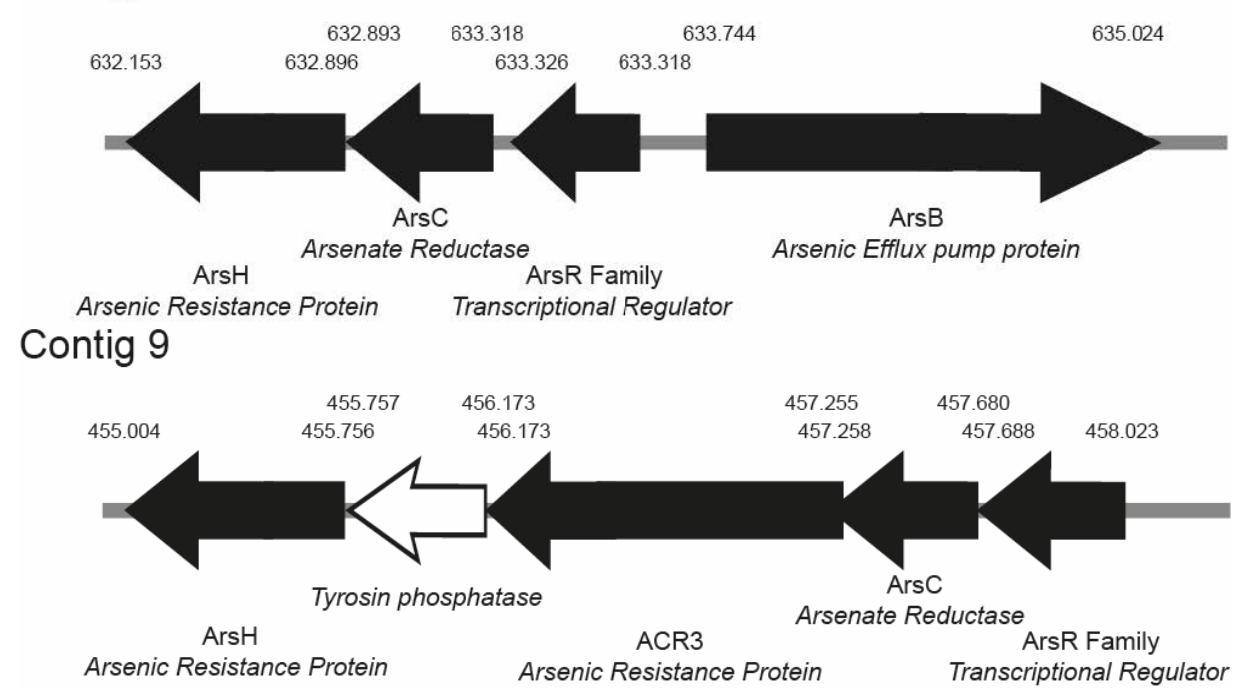

Figure 3. Genetic organization of the two arsenic resistance operon in strain Brevundimonas sp. B10. Gene orientations are shown by arrows.

Metal(loid)s resistance genes were also found in the annotation and are listed in Table 4. It was found that Brevundimonas sp. B10 had several genes related to heavy metal resistance, including $\mathrm{Mg}$ and Co efflux proteins, $\mathrm{Co}-\mathrm{Zn}-\mathrm{Cd}$ efflux transporters, and resistance proteins.

\subsection{Real-Time PCR}

The present study reveals the relative expression of $\operatorname{ars} B, A C R 3$, $\operatorname{ars} H, \operatorname{ars} C$, and arsR genes in Brevundimonas sp. B10 under As stress at different concentrations (500 and $1000 \mathrm{mg} \mathrm{L}^{-1}$ ) analyzed by RT-qPCR (Figure 4). The relative expression of arsH was not induced significantly by the presence of As. The gene $A C R 3$ behave similarly to the control when was submitted to 500 and $1000 \mathrm{mg} \mathrm{L}^{-1}$ of As, the same happened to the relative expression of $\operatorname{ars} R$. The relative expression of $\operatorname{ars} B$ was downregulated between 0.5 and 1 fold under the presence of As. 
Table 4. List of heavy metal resistance-related genes found in Brevundimonas sp. B10.

\begin{tabular}{|c|c|c|}
\hline Annotation & Size (aa) & Accession Number \\
\hline Cobalt-zinc-cadmium resistance protein $C z c A$; Cation efflux system protein $C u s A$ & 1062 & TFW13601.1 \\
\hline $\begin{array}{l}\text { Cobalt/zinc/cadmium efflux RND transporter, membrane fusion protein, } \\
\qquad C z c B \text { family }\end{array}$ & 420 & TFW13602.1 \\
\hline Heavy metal RND efflux outer membrane protein, $C z c C$ family & 438 & TFW13603.1 \\
\hline $\begin{array}{c}\text { Lead, cadmium, zinc and mercury transporting ATPase (EC 3.6.3.3) (EC 3.6.3.5); } \\
\text { Copper-translocating P-type ATPase (EC 3.6.3.4) }\end{array}$ & 782 & TFW13626.1 \\
\hline Copper resistance protein $B$ & 421 & TFW13627.1 \\
\hline Copper resistance protein $\mathrm{CopC}$ & 135 & TFW13611.1 \\
\hline Copper resistance protein $D$ & 311 & TFW13620.1 \\
\hline Copper resistance protein $\operatorname{CopC}$ & 120 & TFW13621.1 \\
\hline Heavy metal RND efflux outer membrane protein, $C z c C$ family & 452 & TFW13623.1 \\
\hline $\begin{array}{l}\text { Cobalt/zinc/cadmium efflux RND transporter, membrane fusion protein, } \\
\qquad C z c B \text { family }\end{array}$ & 433 & TFW13624.1 \\
\hline Copper resistance protein $D$ & 311 & TFW13486.1 \\
\hline Copper resistance protein $\mathrm{CopC}$ & 120 & TFW13487.1 \\
\hline Heavy metal RND efflux outer membrane protein, $C z c C$ family & 452 & TFW13489.1 \\
\hline $\begin{array}{l}\text { Cobalt/zinc/cadmium efflux RND transporter, membrane fusion protein, } \\
\qquad C z c B \text { family }\end{array}$ & 433 & TFW13490.1 \\
\hline Cobalt-zinc-cadmium resistance protein $C z c A$; Cation efflux system protein $C u s A$ & 1050 & TFW13491.1 \\
\hline $\begin{array}{c}\text { Lead, cadmium, zinc and mercury transporting ATPase (EC 3.6.3.3) (EC 3.6.3.5); } \\
\text { Copper-translocating P-type ATPase (EC 3.6.3.4) }\end{array}$ & 718 & TFW13496.1 \\
\hline Cobalt-zinc-cadmium resistance protein $C z c A$; Cation efflux system protein $C u s A$ & 1072 & TFW13501.1 \\
\hline $\begin{array}{l}\text { Cobalt/zinc/cadmium efflux RND transporter, membrane fusion protein, } \\
\qquad C z c B \text { family }\end{array}$ & 402 & TFW13502.1 \\
\hline Heavy metal RND efflux outer membrane protein, $C z c C$ family & 417 & TFW13503.1 \\
\hline
\end{tabular}
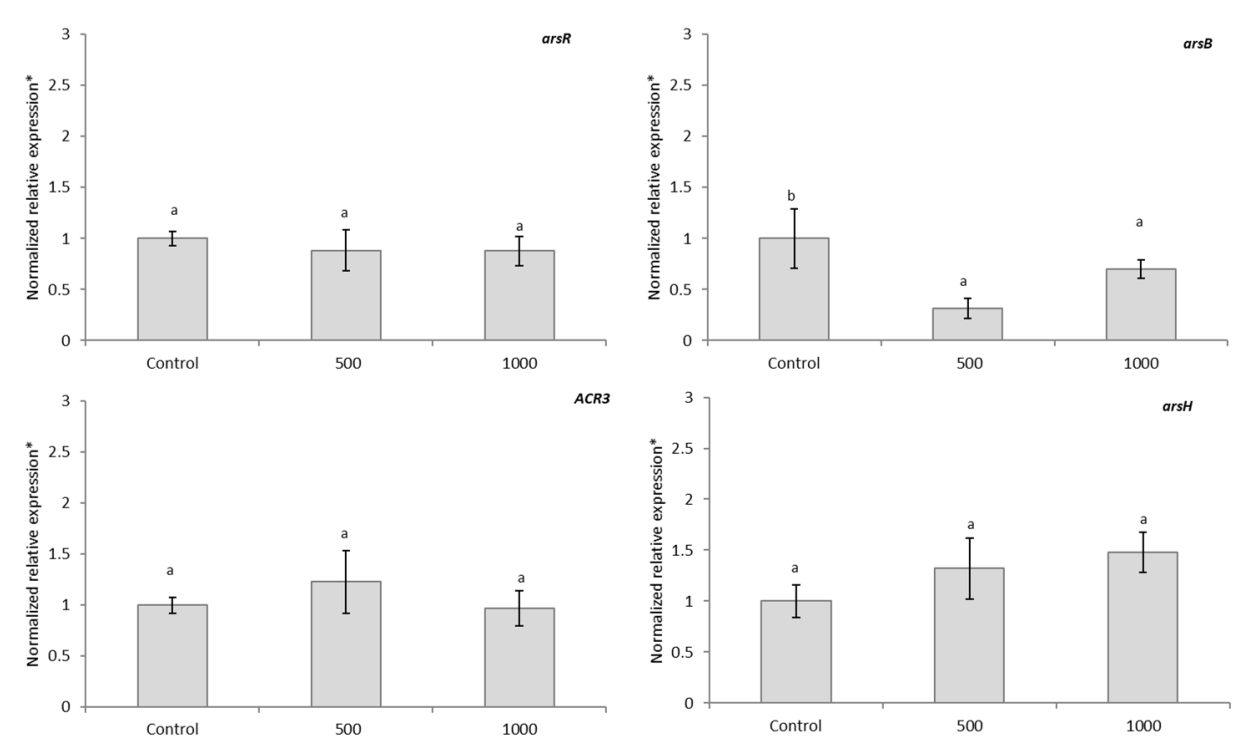

Figure 4. Relative expression of the arsR, arsB, $A C R 3$, and ars $H$ genes in Brevundimonas sp. B10 in LB broth spiked with 500 and $1000 \mathrm{mg} \mathrm{L}^{-1}$ of As. Standard deviation is indicated by different bars and letters show statistically significant differences $(p<0.05) .{ }^{*}$ Normalized to rho and rpoB.

\section{Discussion}

The phylogenetic tree constructed with the genes belonging to the ars operon of Brevundimonas sp. B10 showed greater closeness to those of the genus Corynebacterium, Acidithiobacillus, and Pseudomonas, belonging to the phylum Proteobacteria and Actinobacteria. Further away are the genera Staphylococcus, Serratia, Yersinia, and Acidiphilium, all belonging to the phylum Proteobacteria, except for Staphylococcus, which belongs to Firmicutes. The distribution of arsenic resistance genes reflects the ubiquitous presence of 
arsenic in nature, but they are present even in microbes isolated from putatively arsenic-free habitats [45].

The draft genome sequencing of Brevundimonas sp. B10 showed various defense subsystems related to heavy metals resistance, such as, $\mathrm{As}, \mathrm{Cu}, \mathrm{Zn}$, and chromium $(\mathrm{Cr})$, including the resistance proteins $\mathrm{CopC}, \mathrm{CzcC}, \mathrm{CzcB}, \mathrm{CzcA}$, among others. In previous experiments (data not shown), we observed that this strain, isolated from an environment contaminated with metal(loid)s, besides having high resistance to sodium arsenate (6000 mg L $\left.\mathrm{m}^{-1}\right)$, has moderate resistance to $\mathrm{Cu}\left(150 \mathrm{mg} \mathrm{L}^{-1}\right), \mathrm{Zn}\left(200 \mathrm{mg} \mathrm{L}^{-1}\right)$ and $\mathrm{Cr}$ $\left(150 \mathrm{mg} \mathrm{L}^{-1}\right)$. Growing evidence suggests that environmental organisms are a reservoir of resistance genes, including genes conferring resistance to antibiotics [46]. The high resistance to $\mathrm{AsV}$ might also be related to the widespread AsV resistance genes among bacteria and regardless of the level of As contamination, As-resistant bacteria appear to be phylogenetically diverse and widely distributed in the natural environment [47]. A considerable number of microorganisms are capable of resisting the toxic effects of As, using methods such as AsIII oxidation (to produce the less toxic AsV), extrusion of As from the cell, and minimizing the uptake of As from the environment [48]. The ability of Brevundimonas sp. B10 to resist a high concentration of AsV correlates with the observation in the draft genome of two operons, one with the arsRBCH arrangement and the other with arsRCH plus $A C R 3$. Although the ars $R C B H$ operon arrangement is not as common as arsRBC and arsRDABC, it has been widely detected in bacteria, such as Salmonella enterica [49], Pseudomonas putida [50], Acidithiobacillus caldus [51], Acidothiobacillus ferrooxidans [52], Serratia marcescens [53], among others. Thereby, the ars-resistance system seems to be a common bacterial mechanism for evading the toxic effects of AsIII and AsV. And more specifically referring to Brevundimonas, several As resistance genes are found in other species of this genus; for example, the ars $C$ gene is found in $B$. vesicularis (accession number WP_066626785.1), B. naejangsanensis (WP_025977280.1), B. nasdae (WP_039243957.1), among others; the arsB gene is found in B. vesicularis (WP_066626995.1) and B. nasdae (WP_039244107.1); arsR is found in B. nasdae (WP_039247942.1), B. vesicularis (WP_066629834.1), among others.

To better understand how some of these genes behave under high concentrations of sodium arsenate, we studied the relative expression of $\operatorname{ars} R$, $\operatorname{ars} B, \operatorname{ars} H$, and ACR3 genes through real-time PCR. The relative expression of ars $R$ did not suffer variations in the presence of AsV, this is likely to be associated with the fact that it is an inducible repressor that binds with the promoter region and regulates the ars operon in the presence of AsIII [54]. This means that the absence of AsIII represses ars transcription [55] and in the presence of AsIII, ars $R$ binds to the effector and dissociates from the operator region allowing transcription to proceed [56].

Once AsV is taken up by the cell, it is reduced to AsIII and pumped to the external environment [24]. This enzymatic reduction of $\mathrm{AsV}$ can be performed by the proteins arsC, arrA, and ttr [57]. We did not detect arrA or ttr genes in this study, but we did detect three $\operatorname{ars} C$ genes. However, the in silico primer construction of the ars $C$ gene was not successful, so the relative expression of ars $C$ could not be tested. These data could have helped us understand our observed repression of the arsB gene. The reduced AsIII is transferred to $\operatorname{ars} B$, which is often associated with $\operatorname{ars} A$, an ATPase subunit, and forms an efficient transmembrane AsIII efflux pump [58]. In our study, the analysis of the draft genome of Brevundimonas sp. B10 did not identify an ars $A$ homolog in the organism. Thus, the lack of ars $A$ might reduce the efflux ability of arsB. Studies in Campylobacter jejuni showed that ars $B$ contributes to AsIII resistance, but not AsV resistance [59]. Besides the extrusion mediated by arsB, bacteria also have other strategies for AsIII efflux like GlpF and Aqpz channels [45]. However, neither of the corresponding genes were found in the draft genome. Another AsIII transporter includes the gene encoding As efflux pump ACR3 [60], but the presence of AsV did not affect the relative expression of this gene in Brevundimonas sp. B10. The ACR3 pump may also couple with the arsA ATPase to form a more efficient primary AsIII efflux system [61]. 
Along with arsM, which was not found in the genome of Brevundimonas sp. B10, arsH expands the spectrum of microbial resistance of the ars operon from inorganic to organic arsenicals [45]. In this sense, the expression of ars $H$ did not vary with the As amendment, this may be due to the absence of organic As or because the bacteria does not transform the inorganic As to organic.

\section{Conclusions}

Our results showed that two operons were found in the genome of Brevundimonas sp. B10, which encode $\operatorname{ars} H$, ars $C, \operatorname{ars} R$, arsB, and $A C R 3$ genes, which confer the ability to tolerate up to $6000 \mathrm{mg} \mathrm{L}^{-1} \mathrm{AsV}$. We also found several genes related to heavy metal tolerance, such as $\mathrm{Cu}, \mathrm{Zn}, \mathrm{Cd}, \mathrm{Pb}$, and others. This study provides insight into how this bacterium can survive in multi-contaminated soil with metal(oid)s and the potential use in bioremediation strategies.

Supplementary Materials: The following are available online at https:/ /www.mdpi.com/article/10 .3390/d13080344/s1, Table S1: Genome statistics, Table S2: Project information Genome statistics, Table S3: BUSCO results: The number of single-copy conserved orthologs found in the genome.

Author Contributions: Conceptualization, J.S., T.C.C. and C.A.; methodology, J.S.; validation, J.S., T.C.C. and C.A.; formal analysis, M.D.J.L. and G.L.; investigation, J.S.; resources, H.H., T.C.C. and C.A.; data curation, H.H. and M.D.J.L.; writing—original draft preparation, J.S.; writing—review and editing, J.S., T.C.C., M.D.J.L. and C.A.; supervision, C.A.; funding acquisition, C.A. and T.C.C. All authors have read and agreed to the published version of the manuscript.

Funding: This research was funded by Fondo Nacional de Desarrollo, Científico y Tecnológico, FONDECYT 1211857, and Comisión Nacional de Investigación Científica y Tecnológica, CONICYT Doctoral Scholarship 21140503.

Institutional Review Board Statement: Not applicable.

Informed Consent Statement: Not applicable.

Data Availability Statement: The data presented in this study are openly available in NCBI database: https://www.ncbi.nlm.nih.gov/bioproject/?term=PRJNA505530 and https://www.ncbi.nlm.nih. gov/search/all/?term=SPVH00000000.1.

Conflicts of Interest: The authors declare no conflict of interest.

\section{References}

1. Kumar, S.; Dubey, R.S.; Tripathi, R.D.; Chakrabarty, D.; Trivedi, P.K. Omics and biotechnology of arsenic stress and detoxification in plants: Current updates and prospective. Environ. Int. 2015, 74, 221-230. [CrossRef]

2. Mandal, B.K.; Suzuki, K.T. Arsenic round the world: A review. Talanta 2002, 58, 201-235. [CrossRef]

3. Duruibe, J.O.; Ogwuegbu, M.; Egwurugwu, J. Heavy metal pollution and human biotoxic effects. Int. J. Phys. Sci. 2007, 2, 112-118.

4. Gamboa-Loira, B.; Cebrian, M.E.; Franco-Marina, F.; Lopez-Carrillo, L. Arsenic metabolism and cancer risk: A meta-analysis. Environ. Res. 2017, 156, 551-558. [CrossRef]

5. Garelick, H.; Jones, H.; Dybowska, A.; Valsami-Jones, E. Arsenic pollution sources. In Reviews of Environmental Contamination Volume 197; Springer: Berlin/Heidelberg, Germany, 2009; pp. 17-60.

6. Chandrakar, V.; Naithani, S.C.; Keshavkant, S. Arsenic-induced metabolic disturbances and their mitigation mechanisms in crop plants: A review. Biologia 2016, 71, 367-377. [CrossRef]

7. Finnegan, P.; Chen, W. Arsenic toxicity: The effects on plant metabolism. Front. Physiol. 2012, 3, 182. [CrossRef]

8. Gusman, G.S.; Oliveira, J.A.; Farnese, F.S.; Cambraia, J. Arsenate and arsenite: The toxic effects on photosynthesis and growth of lettuce plants. Acta Physiol. Plant. 2013, 35, 1201-1209. [CrossRef]

9. Huestis, J.; Zhou, X.; Chen, L.; Feng, C.; Hudson, L.G.; Liu, K.J. Kinetics and thermodynamics of zinc (II) and arsenic (III) binding to XPA and PARP-1 zinc finger peptides. J. Inorg. Biochem. 2016, 163, 45-52. [CrossRef]

10. Fayiga, A.O.; Saha, U.K. Arsenic hyperaccumulating fern: Implications for remediation of arsenic contaminated soils. Geoderma 2016, 284, 132-143. [CrossRef]

11. Basu, A.; Mahata, J.; Gupta, S.; Giri, A. Genetic toxicology of a paradoxical human carcinogen, arsenic: A review. Mutat. Res. Rev. Mutat. Res. 2001, 488, 171-194. [CrossRef]

12. Jedynak, L.; Kowalska, J.; Leporowska, A. Arsenic uptake and phytochelatin synthesis by plants from two arsenic-contaminated sites in Poland. Pol. J. Environ. Stud. 2012, 21, 1629-1633. 
13. Rafiq, M.; Shahid, M.; Abbas, G.; Shamshad, S.; Khalid, S.; Niazi, N.K.; Dumat, C. Comparative effect of calcium and EDTA on arsenic uptake and physiological attributes of Pisum sativum. Int. J. Phytoremediat. 2017, 19, 662-669. [CrossRef] [PubMed]

14. Shahid, M.; Dumat, C.; Khalid, S.; Schreck, E.; Xiong, T.; Niazi, N.K. Foliar heavy metal uptake, toxicity and detoxification in plants: A comparison of foliar and root metal uptake. J. Hazard. Mater. 2017, 325, 36-58. [CrossRef] [PubMed]

15. Singh, P.K.; Indoliya, Y.; Chauhan, A.S.; Singh, S.P.; Singh, A.P.; Dwivedi, S.; Tripathi, R.D.; Chakrabarty, D. Nitric oxide mediated transcriptional modulation enhances plant adaptive responses to arsenic stress. Sci. Rep. 2017, 7, 3592. [CrossRef] [PubMed]

16. Talukdar, D. Arsenic-induced changes in growth and antioxidant metabolism of fenugreek. Russ. J. Plant Physiol. 2013, 60, 652-660. [CrossRef]

17. Qin, J.; Rosen, B.P.; Zhang, Y.; Wang, G.; Franke, S.; Rensing, C. Arsenic detoxification and evolution of trimethylarsine gas by a microbial arsenite S-adenosylmethionine methyltransferase. Proc. Natl. Acad. Sci. USA 2006, 103, 2075-2080. [CrossRef]

18. Borch, T.; Kretzschmar, R.; Kappler, A.; Cappellen, P.V.; Ginder-Vogel, M.; Voegelin, A.; Campbell, K. Biogeochemical redox processes and their impact on contaminant dynamics. Environ. Sci. Technol. 2009, 44, 15-23. [CrossRef]

19. Lim, K.; Shukor, M.; Wasoh, H. Physical, chemical, and biological methods for the removal of arsenic compounds. BioMed Res. Int. 2014, 2014, 503784. [CrossRef]

20. Das, S.; Jean, J.-S.; Kar, S.; Chou, M.-L.; Chen, C.-Y. Screening of plant growth-promoting traits in arsenic-resistant bacteria isolated from agricultural soil and their potential implication for arsenic bioremediation. J. Hazard. Mater. 2014, 272, 112-120. [CrossRef]

21. Satyapal, G.K.; Mishra, S.K.; Srivastava, A.; Ranjan, R.K.; Prakash, K.; Haque, R.; Kumar, N. Possible bioremediation of arsenic toxicity by isolating indigenous bacteria from the middle Gangetic plain of Bihar, India. Biotechnol. Rep. 2018, 17, 117-125. [CrossRef]

22. Singh, N.; Gupta, S.; Marwa, N.; Pandey, V.; Verma, P.C.; Rathaur, S.; Singh, N. Arsenic mediated modifications in Bacillus aryabhattai and their biotechnological applications for arsenic bioremediation. Chemosphere 2016, 164, 524-534. [CrossRef] [PubMed]

23. Suhadolnik, M.L.; Salgado, A.P.; Scholte, L.L.; Bleicher, L.; Costa, P.S.; Reis, M.P.; Dias, M.F.; Ávila, M.P.; Barbosa, F.A.; Chartone-Souza, E. Novel arsenic-transforming bacteria and the diversity of their arsenic-related genes and enzymes arising from arsenic-polluted freshwater sediment. Sci. Rep. 2017, 7, 11231. [CrossRef] [PubMed]

24. Rosen, B.P. Families of arsenic transporters. Trends Microbiol. 1999, 7, 207-212. [CrossRef]

25. Silver, S.; Phung, L.T. Genes and enzymes involved in bacterial oxidation and reduction of inorganic arsenic. Appl. Environ. Microbiol. 2005, 71, 599-608. [CrossRef] [PubMed]

26. Rosen, B.P. Biochemistry of arsenic detoxification. FEBS Lett. 2002, 529, 86-92. [CrossRef]

27. Kumar, V.; Gera, R. Isolation of a multi-trait plant growth promoting Brevundimonas sp. and its effect on the growth of Bt-cotton. 3 Biotech 2014, 4, 97-101. [CrossRef]

28. Ji, B.; Chen, W.; Zhu, L.; Yang, K. Isolation of aluminum-tolerant bacteria capable of nitrogen removal in activated sludge. Mar. Pollut. Bull. 2016, 106, 31-34. [CrossRef]

29. Singh, N.; Marwa, N.; Mishra, J.; Verma, P.C.; Rathaur, S.; Singh, N. Brevundimonas diminuta mediated alleviation of arsenic toxicity and plant growth promotion in Oryza sativa L. Ecotoxicol. Environ. Saf. 2016, 125, 25-34. [CrossRef]

30. Ginocchio, R. Effects of a copper smelter on a grassland community in the Puchuncavi Valley, Chile. Chemosphere 2000, 41, 15-23. [CrossRef]

31. Soto, J.; Ortiz, J.; Herrera, H.; Fuentes, A.; Almonacid, L.; Charles, T.C.; Arriagada, C. Enhanced arsenic tolerance in Triticum aestivum inoculated with arsenic-resistant and plant growth promoter microorganisms from a heavy metal-polluted soil. Microorganisms 2019, 7, 348. [CrossRef]

32. Banerjee, S.; Datta, S.; Chattyopadhyay, D.; Sarkar, P. Arsenic accumulating and transforming bacteria isolated from contaminated soil for potential use in bioremediation. J. Environ. Sci. Health Part A 2011, 46, 1736-1747. [CrossRef]

33. Alanjary, M.; Steinke, K.; Ziemert, N. AutoMLST: An automated web server for generating multi-locus species trees highlighting natural product potential. Nucleic Acids Res. 2019, 47, W276-W282. [CrossRef] [PubMed]

34. Kumar, S.; Stecher, G.; Li, M.; Knyaz, C.; Tamura, K. MEGA X: Molecular evolutionary genetics analysis across computing platforms. Mol. Biol. Evol. 2018, 35, 1547-1549. [CrossRef]

35. Bankevich, A.; Nurk, S.; Antipov, D.; Gurevich, A.A.; Dvorkin, M.; Kulikov, A.S.; Lesin, V.M.; Nikolenko, S.I.; Pham, S.; Prjibelski, A.D. SPAdes: A new genome assembly algorithm and its applications to single-cell sequencing. J. Comput. Biol. 2012, 19, 455-477. [CrossRef] [PubMed]

36. Guizelini, D.; Raittz, R.T.; Cruz, L.M.; Souza, E.M.; Steffens, M.B.; Pedrosa, F.O. GFinisher: A new strategy to refine and finish bacterial genome assemblies. Sci. Rep. 2016, 6, 34963. [CrossRef]

37. Li, D.; Liu, C.-M.; Luo, R.; Sadakane, K.; Lam, T.-W. MEGAHIT: An ultra-fast single-node solution for large and complex metagenomics assembly via succinct de Bruijn graph. Bioinformatics 2015, 31, 1674-1676. [CrossRef]

38. Jackman, S.D.; Vandervalk, B.P.; Mohamadi, H.; Chu, J.; Yeo, S.; Hammond, S.A.; Jahesh, G.; Khan, H.; Coombe, L.; Warren, R.L. ABySS 2.0: Resource-efficient assembly of large genomes using a Bloom filter. Genome Res. 2017, 27, 768-777. [CrossRef]

39. Aziz, R.K.; Bartels, D.; Best, A.A.; DeJongh, M.; Disz, T.; Edwards, R.A.; Formsma, K.; Gerdes, S.; Glass, E.M.; Kubal, M. The RAST Server: Rapid annotations using subsystems technology. BMC Genom. 2008, 9, 75. [CrossRef]

40. Hyatt, D.; Chen, G.-L.; LoCascio, P.F.; Land, M.L.; Larimer, F.W.; Hauser, L.J. Prodigal: Prokaryotic gene recognition and translation initiation site identification. BMC Bioinform. 2010, 11, 119. [CrossRef] 
41. Simão, F.A.; Waterhouse, R.M.; Ioannidis, P.; Kriventseva, E.V.; Zdobnov, E.M. BUSCO: Assessing genome assembly and annotation completeness with single-copy orthologs. Bioinformatics 2015, 31, 3210-3212. [CrossRef]

42. Jullien, N. AmplifX 1.7.0; CNRS Aix-Marseille University: Marseille, France, 2013.

43. Vandesompele, J.; De Preter, K.; Pattyn, F.; Poppe, B.; Van Roy, N.; De Paepe, A.; Speleman, F. Accurate normalization of real-time quantitative RT-PCR data by geometric averaging of multiple internal control genes. Genome Biol. 2002, 3, 1-12. [CrossRef] [PubMed]

44. Andersen, C.L.; Jensen, J.L.; Ørntoft, T.F. Normalization of real-time quantitative reverse transcription-PCR data: A model-based variance estimation approach to identify genes suited for normalization, applied to bladder and colon cancer data sets. Cancer Res. 2004, 64, 5245-5250. [CrossRef]

45. Fekih, I.B.; Zhang, C.; Li, Y.P.; Zhao, Y.; Alwathnani, H.A.; Saquib, Q.; Rensing, C.; Cervantes, C. Distribution of arsenic resistance genes in prokaryotes. Front. Microbiol. 2018, 9, 2473. [CrossRef] [PubMed]

46. Bhullar, K.; Waglechner, N.; Pawlowski, A.; Koteva, K.; Banks, E.D.; Johnston, M.D.; Barton, H.A.; Wright, G.D. Antibiotic resistance is prevalent in an isolated cave microbiome. PLoS ONE 2012, 7, e34953.

47. Achour, A.R.; Bauda, P.; Billard, P. Diversity of arsenite transporter genes from arsenic-resistant soil bacteria. Res. Microbiol. 2007, 158, 128-137. [CrossRef]

48. Garbinski, L.D.; Rosen, B.P.; Chen, J. Pathways of arsenic uptake and efflux. Environ. Int. 2019, 126, 585-597. [CrossRef]

49. Falgenhauer, L.; Ghosh, H.; Guerra, B.; Yao, Y.; Fritzenwanker, M.; Fischer, J.; Helmuth, R.; Imirzalioglu, C.; Chakraborty, T. Comparative genome analysis of IncHI2 VIM-1 carbapenemase-encoding plasmids of Escherichia coli and Salmonella enterica isolated from a livestock farm in Germany. Vet. Microbiol. 2017, 200, 114-117. [CrossRef]

50. Páez-Espino, A.D.; Durante-Rodríguez, G.; de Lorenzo, V. Functional coexistence of twin arsenic resistance systems in Pseudomonas putida KT 2440. Environ. Microbiol. 2015, 17, 229-238. [CrossRef]

51. Dopson, M.; Lindström, B.E.; Hallberg, K.B. Chromosomally encoded arsenical resistance of the moderately thermophilic acidophile Acidithiobacillus caldus. Extremophiles 2001, 5, 247-255. [CrossRef]

52. De Groot, P.; Deane, S.M.; Rawlings, D.E. A transposon-located arsenic resistance mechanism from a strain of Acidithiobacillus caldus isolated from commercial, arsenopyrite biooxidation tanks. Hydrometallurgy 2003, 71, 115-123. [CrossRef]

53. Ryan, D.; Colleran, E. Arsenical resistance in the IncHI2 plasmids. Plasmid 2002, 47, 234-240. [CrossRef]

54. Zhou, T.; Radaev, S.; Rosen, B.P.; Gatti, D.L. Structure of the ArsA ATPase: The catalytic subunit of a heavy metal resistance pump. EMBO J. 2000, 19, 4838-4845. [CrossRef] [PubMed]

55. Xu, C.; Shi, W.; Rosen, B.P. The chromosomal arsR gene of Escherichia coli encodes a trans-acting metalloregulatory protein. J. Biol. Chem. 1996, 271, 2427-2432. [CrossRef]

56. Wu, J.; Rosen, B. Metalloregulated expression of the ars operon. J. Biol. Chem. 1993, 268, 52-58. [CrossRef]

57. Blum, J.S.; Hernandez-Maldonado, J.; Redford, K.; Sing, C.; Bennett, S.C.; Saltikov, C.W.; Oremland, R.S. Arsenate-dependent growth is independent of an ArrA mechanism of arsenate respiration in the termite hindgut isolate Citrobacter sp. strain TSA-1. Can. J. Microbiol. 2018, 64, 619-627. [CrossRef] [PubMed]

58. Dey, S.; Rosen, B.P. Dual mode of energy coupling by the oxyanion-translocating ArsB protein. J. Bacteriol. 1995, 177, 385-389. [CrossRef]

59. Shen, Z.; Han, J.; Wang, Y.; Sahin, O.; Zhang, Q. The contribution of ArsB to arsenic resistance in Campylobacter jejuni. PLoS ONE 2013, 8, e58894. [CrossRef] [PubMed]

60. Yang, H.-C.; Fu, H.-L.; Lin, Y.-F.; Rosen, B.P. Pathways of arsenic uptake and efflux. In Current Topics in Membranes; Elsevier: Amsterdam, The Netherlands, 2012; Volume 69, pp. 325-358.

61. Castillo, R.; Saier, M.H. Functional promiscuity of homologues of the bacterial ArsA ATPases. Int. J. Microbiol. 2010, 2010, 187373. [CrossRef] [PubMed] 